Review

\title{
Secondary Metabolites from Marine Sponges of the Genus Oceanapia: Chemistry and Biological Activities
}

\author{
Meng-Juan Xu, Lin-Jing Zhong, Jun-Kun Chen, Qing Bu and Lin-Fu Liang *D \\ College of Materials Science and Engineering, Central South University of Forestry and Technology, \\ Changsha 410004, China; shine0805@163.com (M.-J.X.); zljswan120101@163.com (L.-J.Z.); \\ cjk_kg@outlook.com (J.-K.C.); $17355249596 @ 163 . c o m(Q . B$. \\ * Correspondence: lianglinfu@csuft.edu.cn
}

Citation: Xu, M.-J.; Zhong, L.-J.; Chen, J.-K.; Bu, Q.; Liang, L.-F. Secondary Metabolites from Marine Sponges of the Genus Oceanapia: Chemistry and Biological Activities. Mar. Drugs 2022, 20, 144. https:/ / doi.org/10.3390/md20020144

Academic Editors: Yonghong Liu and Xuefeng Zhou

Received: 10 December 2021 Accepted: 11 February 2022 Published: 16 February 2022

Publisher's Note: MDPI stays neutral with regard to jurisdictional claims in published maps and institutional affiliations.

Copyright: () 2022 by the authors Licensee MDPI, Basel, Switzerland. This article is an open access article distributed under the terms and conditions of the Creative Commons Attribution (CC BY) license (https:// creativecommons.org/licenses/by/ $4.0 /)$.

\begin{abstract}
In this review, we summarized the distribution of the chemically investigated Oceanapia sponges, including the isolation and biological activities of their secondary metabolites, covering the literature from the first report in 1989 to July 2019. There have been 110 compounds reported during this period, including 59 alkaloids, 33 lipids, 14 sterols and 4 miscellaneous compounds. Besides their unique structures, they exhibited promising bioactivities ranging from insecticidal to antibacterial. Their complex structural characteristics and diverse biological properties have attracted a great deal of attention from chemists and pharmaceuticals seeking to perform their applications in the treatment of disease.
\end{abstract}

Keywords: Oceanapia; sponge; secondary metabolites; biological activities

\section{Introduction}

Marine sponges, living in harsh marine conditions from tropic to polar regions, offer an enormous source of natural products bearing unique structures and significant bioactivities, making them ideal candidates for drug discovery projects [1]. Of them, the animals belonging to the genus Oceanapia (phylum, Porifera; class, Demospongiae; subclass, Heteroscleromorpha; order, Haplosclerida; family, Phloeodictyidae) have proven to be a biochemical warehouse for secondary metabolites, such as alkaloids, lipids, sterols, etc. It is particularly interesting that these compounds exhibited a wide range of biological features ranging from antibacterial and cytotoxic to ichthyotoxic activities [2]. In order to better understand the natural products from this genus, there would be a demand for a review.

Notably, several other generic names (Phloeodictyon Carter, 1882; Rhizochalina Schmidt, 1870; Biminia Wiedenmayer, 1977; Foliolina Schmidt, 1870) are now considered as synonyms for Oceanapia [3]. However, there is no associated reference on secondary metabolites of two genera Biminia and Foliolina listed in SciFinder Scholar. Therefore, this review covers topics on three nominal genera, Oceanapia, Phloeodictyon and Rhizochalina, covering different types of compounds, with a literature survey from 1989 to July 2019. During this period, 110 compounds have been reported, including 59 alkaloids, 33 lipids, 14 sterols and 4 other miscellaneous compounds. More than eight species of Oceanapia sponges have been chemically investigated including Oeanapia sagittaria, Oceanapia fistulosa, Oceanapia bartschi, Phloeodictyon sp., Rhizochalina incrustata, Oceanapia ramsayi, Oceanapia phillipensis, Oceanupia cf. tenuis and Oceanapia sp. The global distribution of the chemically investigated marine Oceanapia sponges according to their species is shown in Figure 1. 


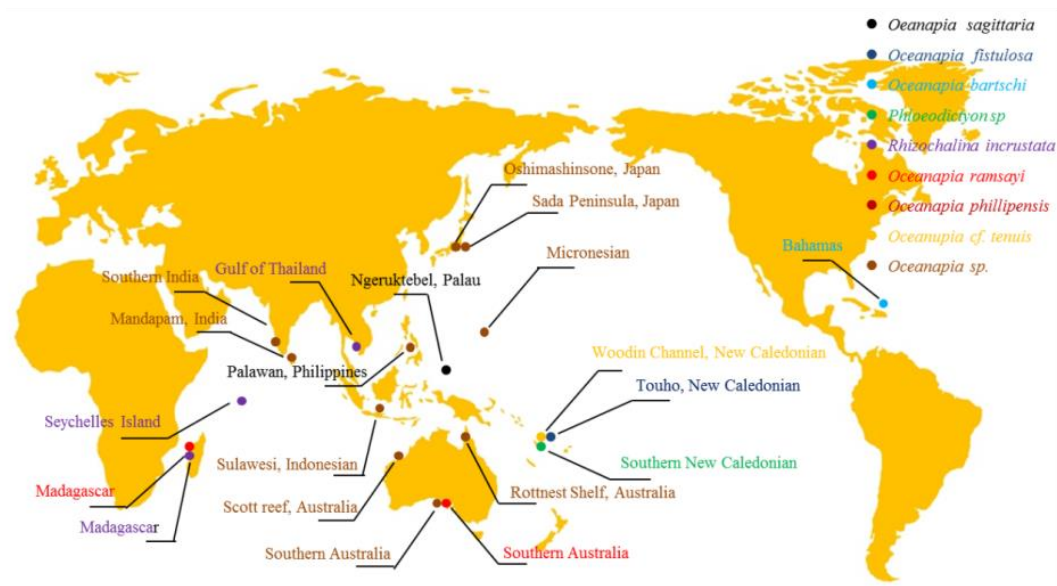

Figure 1. Global distribution of the chemically investigated marine Oceanapia sponges according to their species.

\section{Alkaloids}

Alkaloids were encountered most frequently. They can be classified as pyridoacridine alkaloids, quinolizidine alkaloids, sesquiterpene alkaloid, phloeodictine alkaloidalkaloids, bromotyrosine alkaloids, indole alkaloids and nucleotide alkaloids, according to their skeletons.

\subsection{Pyridoacridine Alkaloids}

Faulkner's group found the sponge Oceanapia sagittaria from Palau contained two pyridoacridine alkaloids dercitamide (1) and sagitol (2) (Figure 2). Of them, 2 was the first pyridoacridine alkaloid from a marine sponge in which the aromatic system had been disrupted. Interestingly, 2 could be obtained by autoxidation of $\mathbf{1}$. Faulkner et al. suggested that 2 was not an artifact that was supported by CD measurements. [4]. Two years later, Proksch et al. reported three pyridoacridine alkaloids kuanoniamine C (1), kuanoniamine D (3) and $N$-deacetylkuanoniamine $\mathrm{C} \mathrm{(4)}$ were afforded by the Micronesian sponge Oceanapia sp. [5]. It may be worthy to point out that the structures of dercitamide and kuanoniamide $C$ were established to be identical by Faulkner and his co-workers [6]. Herein, the same numbering was assigned for these two different nomenclative compounds. Proksch et al. performed many bioassays for these three alkaloids. When incorporated into an artificial diet, compounds $\mathbf{1}$ and $\mathbf{3}$ exhibited insecticidal activity toward neonate larvae of the polyphagous pest insect Spodoptera littoralis ( $\mathrm{LC}_{50}$ of 156 and $59 \mathrm{ppm}$, respectively). Both compounds also showed toxicity in the brine shrimp lethality test with $\mathrm{LC}_{50}$ values of 37 and $19 \mu \mathrm{g} / \mathrm{mL}$, respectively. Although the $N$-deacyl derivative 4 did not show any remarkable effect in either of the abovementioned bioassays, it appeared to be active in the cytotoxic biotests against two human cell lines. The $\mathrm{IC}_{50}$ of 4 was $1.2 \mu \mathrm{g} / \mathrm{mL}$ toward HeLa cells and $2.0 \mu \mathrm{g} / \mathrm{mL}$ toward MONO-MAC 6 cells. In receptor binding assays, compound 3 showed affinity to $\mathrm{A}_{1}$ - and $\mathrm{A}_{2 \mathrm{~A}}$-adenosine receptors with $K_{\mathrm{i}}$ values of 2.94 and $13.7 \mu \mathrm{M}$, respectively. Compound $\mathbf{1}$ was less active than its homologue 3 , whereas the $\mathrm{N}$-deacyl derivative 4 showed no affinity toward adenosine receptors. In addition, compounds 1, 3 and 4 exhibited moderate affinity to benzodiazepine binding sites of $\mathrm{GABA}_{\mathrm{A}}$ receptors [5]. Meanwhile, Proksch et al. explored the distribution of compounds $\mathbf{1}$ and $\mathbf{3}$ in the sponge Oceanapia sp., as well as its ecological implications. It was found that the secondary metabolites $\mathbf{1}$ and $\mathbf{3}$ showed a sharp increase from the basal root to the capitum. The feeding assays against the spongivorous angelfish Pomacanthus imperator showed that $\mathbf{1}$ and $\mathbf{3}$ significantly deterred feeding by natural assemblages of reef fishes at fistule concentrations, confirming their role as defensive agents [7]. 
<smiles>[R]NCCc1c2c3c(c4ncsc14)N=CCC3=C1C=CC=CC1N2</smiles>

$1 \mathrm{R}=\mathrm{COCH}_{2} \mathrm{CH}_{3}$ $3 \mathrm{R}=\mathrm{COCH}_{3}$ $4 \mathrm{R}=\mathrm{H}$<smiles>[R]NCC[C@]1(O)C2=NC3C=CC=CC3=C3CC=NC(=C23)c2scnc21</smiles>

$2 \mathrm{R}=\mathrm{COCH}_{2} \mathrm{CH}_{3}$ $7 \mathrm{R}=\mathrm{COCH}\left(\mathrm{CH}_{3}\right)_{2}$<smiles>O=C1C2=NC3C=CC=CC3=C3CC=NC(=C23)c2ncsc21</smiles>

5<smiles>CN1CC(=O)c2c3cc(Br)ccc3nc3c2c1c(O)c1c[n+](C)ccc13</smiles>

6

Figure 2. The chemical structures of pyridoacridine alkaloids 1-7.

Kijjoa and his co-workers reported another specimen, O. sagittaria from the Gulf of Thailand, afforded kuanoniamine C (1) and its relative compound kuanoniamine A (5). In this study, compounds $\mathbf{1}$ and $\mathbf{5}$ were evaluated for cytotoxic effects against five human tumor cell lines MCF-7 (ER+), MDA-MB-231 (ER-), SF-268, NCI-H460 and UACC-62, and one human non-tumor cell line, MRC-5, by the SRB method. Compound 5 was found to be a potent growth inhibitor of all tumor and the non-tumor cell lines while $\mathbf{1}$ was less potent but showed high selectivity toward the estrogen-dependent $(\mathrm{ER}+)$ breast cancer cell line MCF-7. Furthermore, 5 was shown to be a more potent inhibitor of DNA synthesis than 1. It was also found that 5 caused an extensive reduction in the MCF-7 cells in the G2/M phase as well as an increase in the apoptotic cells [8].

Bioassay-guided fractionation of the $\mathrm{MeOH}$ extract of an Australian sponge Oceanapia sp. performed by Carroll's group, using the aspartyl semialdehyde dehydrogenase (ASD) to detect antibacterial activity, led to the discovery of a bright blue compound, petrosamine B (6). It was found 6 was a weak inhibitor of ASD with an $\mathrm{IC}_{50}$ of $306 \mu \mathrm{M}$ [9]. In Ibrahim's investigation of the Indonesian sponge Oceanapia sp., sagitol C (7) together with the two abovementioned compounds $\mathbf{1}$ and $\mathbf{2}$ were disclosed. The cytotoxic effect of $\mathbf{7}$ was tested against mouse lymphoma (L5178Y), rat brain (PC12) and human cervix (Hela) cell lines. It exhibited $93 \%, 88 \%$ and $76 \%$ growth suppression against the tested cell lines at a concentration of $24.6 \mu \mathrm{M}$ and $81 \%, 74 \%$ and $37 \%$ at a concentration of $12.3 \mu \mathrm{M}$ with $\mathrm{ED}_{50}$ values of $0.7,0.9$ and $2.3 \mu \mathrm{M}$, respectively [10].

\subsection{Quinolizidine Alkaloids}

A bisquinolizidine alkaloid, petrosin (8), and a series of bis-1-oxaquinolizidine alkaloids, xestospongins C-J (9-16) (Figure 3), were all obtained by Singh and his partners from the ethyl acetate extract of the sponge Oceanapia sp., which was collected from the southern coast of India. The relative stereochemistry of $\mathbf{8}$ was established by single-crystal $\mathrm{X}$-ray analysis as $1 S^{*}, 2 R^{*}, 4 R^{*}, 9 S^{*}, 15 R^{*}, 17 R^{*}, 22 S^{*}, 23 S^{*}$. Compounds 9 and 10 were found to be active against several pathogens such as Cryptococcus neoformans, Aspergillus funigatus, Candida albicans and Aspergillus niger [11].

\subsection{Sesquiterpene Alkaloid}

Faulkner's group disclosed the major metabolite of the Philippine sponge Oceanapia sp. was the antimicrobial alkaloid oceanapamine (17) (Figure 4), isolated as trifluoroacetate (TFA) salt. The structure of $\mathbf{1 7}$ consisted of a monocyclic sesquiterpene attached to a histamine residue, representing the sole sesquiterpene-alkaloid hybrid from the genus Oceanapia. Compared with related model compounds, the absolute configuration of 17 was assigned as $6 R$. The TFA salt of $\mathbf{1 7}$ was screened rather broadly but only exhibited antimicrobial activity. In the standard disk (6- $\mathrm{mm})$ assay, 17 inhibited Bacillus subtilis and Escherichia coli at $25 \mu \mathrm{g} /$ disk, Staphyloccocus aureus and C. albicans at $50 \mu \mathrm{g} / \mathrm{disk}$ and Pseudomonas aerioginosa at $100 \mu \mathrm{g} /$ disk [12]. 


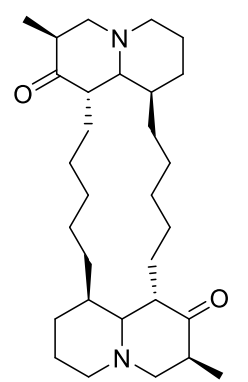

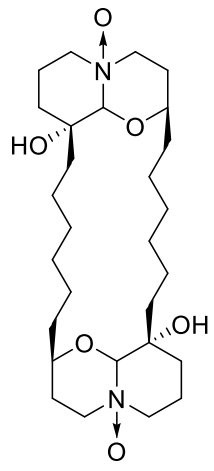

13

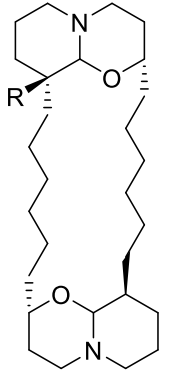

$9 \mathrm{R}=\mathrm{H}$ $10 \mathrm{R}=\mathrm{OH}$<smiles>C[C@@H]1CN2CCC[C@@H]3CCCCCC[C@@H]4CCN5CCCC(CCCCCCC[C@@H]1OC32)C5O4</smiles>

14

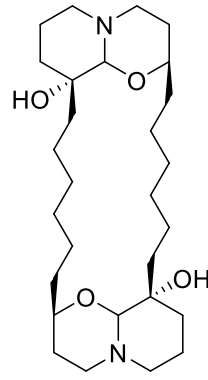

11

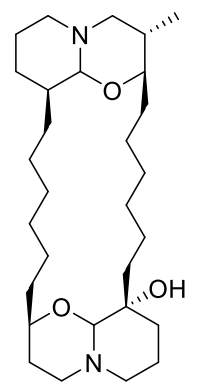

15

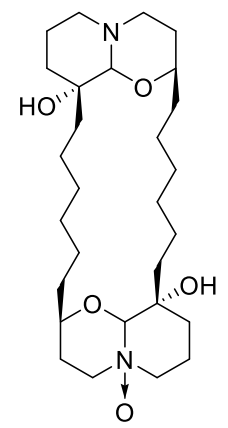

12

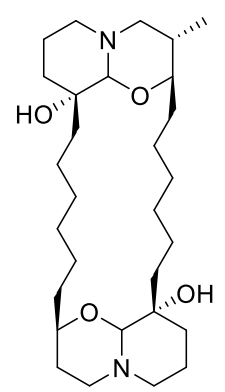

16

Figure 3. The chemical structures of quinolizidine alkaloids 8-16.<smiles>C=C1CCCC(C)(C)[C@@H]1CC/C(C)=C/Cc1nc[nH]c1CCN</smiles>

17

Figure 4. The chemical structure of sesquiterpene alkaloid 17.

\subsection{Phloeodictine Alkaloids}

The phloeodictyne framework was characterized by a fused alkaloidal skeleton, 1,2,3,4tetrahydropyrrolo[1,2-a]pyrimidinium, bearing a variable-length alkyl (or alkenyl) side chain at C-6 and a four / five methylene chain ending in a guanidine group at $N-1$, while a thioethylguanidine chain may have been present at C-7 or not. Kourany-Lefoll et al. first reported this group of alkaloids in the haplosclerid sponge Phloeodictyon sp. living in deep New Caledonian waters. Included were the pure compounds phloeodictines A (18) and B (19) and the inseparable mixtures of phloeodictines A1 (20) and A2 (21), A3 (22), A4 (23) and A5 (24), A6 (25) and A7 (26) and C1 (27) and C2 (28) (Figure 5). Compounds 18 and 19 had been tested against several bacteria using the standard microdilution plate assay and revealed to have potent activity with the following respective MICs $(\mu \mathrm{g} / \mathrm{mL})$ : S. aureus $(1,3)$, E. coli $(1,30)$, P. aeruginosa $(10,>30)$ and Streptococcus fecalis $(5,>15)$. On the other hand, the mixtures A $(20+21), B(22+23+24), C(25+26)$ and D $(27+28)$ were found to possess a wider spectrum of antibacterial activity (respective MICs, $\mu \mathrm{g} / \mathrm{mL}$ ): $S$. aureu $(3,30,1,3)$, E. coli $(3,30,3,>30)$, P. aeruginosa $(30,>30,30,>30)$, Clostridium perfringens $(30,>30,1,>100)$, Bucteroides frugilis $(10, \sim 30,3,>100)$ and Peptococcus assacckarolyticus $(10,>30,3,>100)$. Furthermore, compounds 18, 19 and mixtures A-D also exhibited in vitro cytotoxicity toward $\mathrm{KB}$ human nasopharyngeal carcinoma cells with $\mathrm{IC}_{50}$ values of $1.5,11.2$, $2.2,3.5,0.6$ and $1.8 \mu \mathrm{g} / \mathrm{mL}$, respectively $[13,14]$. Ten years later, Snider and his co-worker completed the first synthesis of $( \pm)-21$ [15]. 


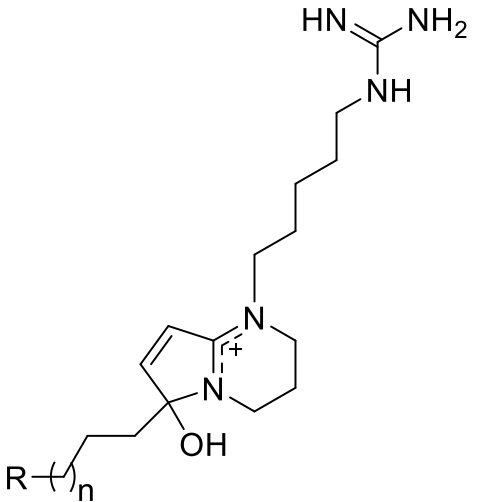

$20 \mathrm{n}=7, \mathrm{R}=-\mathrm{CH}_{2} \mathrm{CH}=\mathrm{CH}_{2}$

$22 \mathrm{n}=5, \mathrm{R}=-\mathrm{CH}_{2} \mathrm{CH}=\mathrm{CH}_{2}$

$24 \mathrm{n}=4, \mathrm{R}=-\mathrm{CH}_{2} \mathrm{CH}=\mathrm{CH}_{2}$

$25 \mathrm{n}=8, \mathrm{R}=-\mathrm{CH}\left(\mathrm{CH}_{3}\right)_{2}$

$29 \mathrm{n}=4, \mathrm{R}=-\mathrm{CH}\left(\mathrm{CH}_{3}\right)_{2}$

$30 \mathrm{n}=5, \mathrm{R}=-\mathrm{CH}\left(\mathrm{CH}_{3}\right)_{2}$

$31 \mathrm{n}=6, \mathrm{R}=-\mathrm{CH}\left(\mathrm{CH}_{3}\right)_{2}$

$32 \mathrm{n}=7, \mathrm{R}=-\mathrm{CH}\left(\mathrm{CH}_{3}\right)_{2}$

$33 \mathrm{n}=8, \mathrm{R}=-\mathrm{CH}_{2} \mathrm{CH}=\mathrm{CH}_{2}$

$34 \mathrm{n}=9, \mathrm{R}=-\mathrm{CH}_{2} \mathrm{CH}=\mathrm{CH}_{2}$

$35 \mathrm{n}=9, \mathrm{R}=-\mathrm{CH}\left(\mathrm{CH}_{3}\right)_{2}$

$36 n=10, \mathrm{R}=-\mathrm{CH}_{2} \mathrm{CH}=\mathrm{CH}_{2}$

$37 \mathrm{n}=10, \mathrm{R}=-\mathrm{CH}\left(\mathrm{CH}_{3}\right)_{2}$<smiles>[R]=[W]CCC1(O)C=CC2=[N+]1CCCN2CCCCNC(=N)N</smiles>

$18 \mathrm{n}=9, \mathrm{R}=-\mathrm{CH}_{2} \mathrm{CH}=\mathrm{CH}_{2}$

$21 \mathrm{n}=7, \mathrm{R}=-\mathrm{CH}_{2} \mathrm{CH}=\mathrm{CH}_{2}$

$23 \mathrm{n}=5, \mathrm{R}=-\mathrm{CH}_{2} \mathrm{CH}=\mathrm{CH}_{2}$

$26 \mathrm{n}=8, \mathrm{R}=-\mathrm{CH}\left(\mathrm{CH}_{3}\right)_{2}$

$38 \mathrm{n}=5, \mathrm{R}=-\mathrm{CH}\left(\mathrm{CH}_{3}\right)_{2}$

$39 \mathrm{n}=6, \mathrm{R}=-\mathrm{CH}_{2} \mathrm{CH}=\mathrm{CH}_{2}$

$40 \mathrm{n}=6, \mathrm{R}=-\mathrm{CH}\left(\mathrm{CH}_{3}\right)_{2}$

$41 \mathrm{n}=7, \mathrm{R}=-\mathrm{CH}\left(\mathrm{CH}_{3}\right)_{2}$

$42 \mathrm{n}=8, \mathrm{R}=-\mathrm{CH}_{2} \mathrm{CH}=\mathrm{CH}_{2}$

$43 \mathrm{n}=10, \mathrm{R}=-\mathrm{CH}_{2} \mathrm{CH}=\mathrm{CH}_{2}$

$44 \mathrm{n}=10, \mathrm{R}=-\mathrm{CH}\left(\mathrm{CH}_{3}\right)_{2}$

$45 \mathrm{n}=11, \mathrm{R}=-\mathrm{CH}_{2} \mathrm{CH}=\mathrm{CH}_{2}$

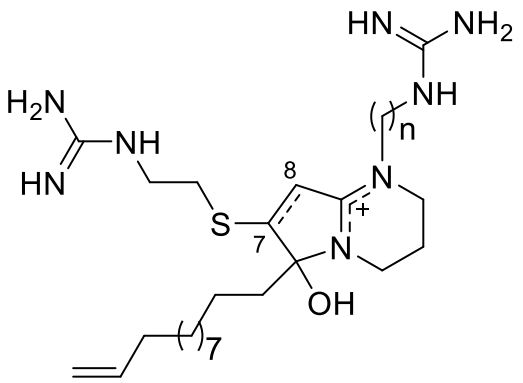

$19 \mathrm{n}=4, \Delta^{7}$

$27 n=4$

$28 n=5$

Figure 5. The chemical structures of phloeodictine alkaloids 18-45.

Phloeodictines were also found to be components of the sponge Oceanapia [= Phloeodictyon] fistulosa in New Caledonian shallow waters by Mancini et al. They were clarified as a wide structural variety including the known 18-28 and new analogues 29-45 as corresponding mixtures. The complexity of the mixtures, and the very similar behavior of their components, prevented their isolation in pure form. However, crude mixtures and HPLC-enriched fractions were suitable for bioassays and proved to be active against chloroquine-resistant Plasmodium falciparum, with $\mathrm{IC}_{50}$ values ranging from 0.6 to $6 \mu \mathrm{M}$, while cytotoxicity against the human A-549 cell line was low. These biological data might serve to illustrate preliminary structure-activity relationships: 1 . The length of the C-6 chain had a greater influence on the bioactivity level than the nature of its terminal portion; 2. methylation of the guanidine moiety lowered the activity. This study showed good prospects for these alkaloids as leads for novel antimalarial agents [16].

\subsection{Bromotyrosine Alkaloids}

Four bromotyrosine alkaloids 46-49 (Figure 6) were all isolated from an Australian non-verongid sponge Oceanapia sp. by Bewley's group. Among them, 46 contained an unprecedented imidazolyl-quinolinone substructure attached to a bromotyrosine-derived spiro-isoxazoline. In the bioassay, compounds 46-49 inhibited mycothiol $S$-conjugate amidase by $50 \%$ at $2,100,3$ and $37 \mathrm{mM}$, respectively. These four alkaloids represented the first examples of natural products that inhibited an enzyme central to a mycothioldependent detoxification pathway found in mycobacteria [17]. 
<smiles>COC1=C(Br)C(Br)=C[C@]2(CC(C(=O)NCCC3NC(N)=NC3c3cc(O)c4[nH]cc(O)c(=O)c4c3O)N2)O1</smiles>

46<smiles>COC1=C(Br)[C@@H](O)[C@]2(C=C1Br)CC(C(=O)NCCc1cnc(N)[nH]1)=NO2</smiles><smiles>N=C(N)NCCCCNC(=O)C(O)(Cc1cc(Br)c(OCCCN)c(Br)c1)[N+](=O)[O-]</smiles>

47<smiles>NCCCOc1c(Br)cc(CC(=O)C(=O)NCCc2cnc(N)[nH]2)cc1Br</smiles>

49

Figure 6. The chemical structures of bromotyrosine alkaloids $46-49$.

\subsection{Indole Alkaloids}

6-Bromo-5-hydroxy-3-indolecarboxyaldehyde (50) along with two other brominated indoles 6-bromo-3-indolecarboxyaldehyde (51) and 3-bromoindole (52) (Figure 7) were discovered in the Caribbean sponge Oceanapia bartschi by Fattorusso's group [18]. Their structurally related non-brominated indole 3-formylindole (53) was disclosed in the Thai sponge O. sagittaria [8]. Crews' group investigated the Indonesian sponge Oceanapia sp., leading to another two brominated indoles, 6-Br-conicamin (54) and 6-Br-8-keto-conicamin A (55). Meanwhile, they synthesized 55 in this study. In the bioassay, the low micromolar in vitro activity of 55 against the PANC-1 cell line ( $\mathrm{IC}_{50} 1.5 \mathrm{mM}$ for the natural product vs. $4.1 \mathrm{mM}$ for the synthetic material) was exciting, which was similar to that of the clinical therapeutics (5FU: $\mathrm{IC}_{50}=7.0 \mathrm{mM}$; gemcitabine: $\mathrm{IC}_{50}=0.02 \mathrm{mM}$ ). Furthermore, ten additional analogs were prepared for further study on the structure-activity relationship. The continued study indicated that the quaternary amine functionality and bromination of the indole ring of $\mathbf{5 5}$ were critical for activity against PANC-1 [19]. The Indian sponge Oceanapia sp. afforded coixol (56), an active compound in the brine shrimp assay $\left(\mathrm{LC}_{50}=52.93 \pm 6.48 \mathrm{ppm}\right)$. This was the first report of coixol from a marine source [20].<smiles>O=Cc1c[nH]c2cc(Br)c(O)cc12</smiles>

50<smiles>CN(C)C=Cc1c[nH]c2cc(Br)ccc12</smiles>

54<smiles>O=Cc1c[nH]c2cc(Br)ccc12</smiles>

51<smiles>Brc1c[nH]c2ccccc12</smiles>

52<smiles>O=Cc1c[nH]c2ccccc12</smiles>

53

Figure 7. The chemical structures of indole alkaloids 50-56. 


\subsection{Nucleotide Alkaloids}

In the study of an Australian sponge Oceanapia sp., uranidine (57) (Figure 8) was discovered as one component of the major alkaloids [17]. Very recently, $N^{6}$-isopentenyladenosine $\left(i^{6} \mathrm{~A}, 58\right)$, along with $N^{6}$-isopentenyladenosine $5^{\prime}$-monophosphate $\left(i^{6} \mathrm{AP}, 59\right)$, was isolated from a Japanese sponge Oceanapia sp. This was the first report of $\mathrm{i}^{6} \mathrm{~A}(58)$ and $\mathrm{i}^{6} \mathrm{AP}(59)$ from a marine sponge. In the cytotoxic biotest, 58 exhibited cytotoxic activity against $\mathrm{HeLa}$ cells with an $\mathrm{IC}_{50}$ value of $2.1 \mu \mathrm{M}$. On the other hand, 59 was inactive at a concentration of $50 \mu \mathrm{M}$. Further observations demonstrated that the cell cycle was arrested at the G1 phase by 58 , which indicated targeting of the Akt/NF- $\mathrm{KB}$ pathway [21].<smiles>O=c1c(O)c[nH]c2c(O)ccc(O)c12</smiles>

57<smiles></smiles>

Figure 8. The chemical structures of nucleotide alkaloids 57-59.

\section{Lipids}

Lipids were the second-largest group of the Oceanapia secondary metabolites. They could be divided into sphingolipids, ceramides and cerebrosides, dithiocyanates and polyacetylenes, according to their structure features.

\subsection{Sphingolipids}

An antimicrobial galactopyranosyl pseudodimeric $\alpha, \omega$-bipolar sphingolipid, rhizochalin (60) (Figure 9), was isolated by Makarieva et al. from the sponge Rhizochalina incrustata near the north-west shore of Madagascar Island [22]. This was the first report of sphingolipids in the sponge of the genus Oceanapia. The effects of $\mathbf{6 0}$ on cell membranes were studied in Ehrlich ascites cells, spleen lymphocytes and erythrocytes, and phospholipid liposomes, respectively. At $10-100 \mathrm{mg} / \mathrm{mL}$, this compound altered membrane permeability. These effects might be related to the cytostatic activity of 60 [23]. Ten years later, Molinski and his co-workers determined the absolute stereochemistry of (-)-rhizochalin (60) as $2 R, 3 R, 26 R, 27 R$ by application of a general CD method based on the superposition of additive exaction couplings in tetrabenzoyl derivatives of bis-amino alkanols [24]. In Gaydou et al.'s study of a specimen of Oceanapia ramsayi collected at Itampolo on the west coast of Madagascar, rhizochalin (60) was found together with its corresponding aglycone rhizochalinin (61), which were both identified by their corresponding peracetates 60a and 61a [25]. A series of cytotoxic bioassays for $\mathbf{6 0}$ and $\mathbf{6 1}$ against different cell lines including the mechanisms had been carried out. Fedorov et al. reported $\mathbf{6 0}$ and $\mathbf{6 1}$ were cytotoxic against JB6 P+ Cl41, HeLa and THP-1 cell lines with $\mathrm{IC}_{50}$ values ranging from 2.8 to $22.1 \mu \mathrm{M}$. A more in-depth study revealed 60 inhibited the EGF-induced transformation of JB6 P+ Cl41 cells in a dose-dependent manner [26]. Stonik and Kwak observed $\mathbf{6 0}$ and $\mathbf{6 1}$ induced apoptosis of HL-60 cells, of which the latter showed a stronger ability. Further detailed study showed the usual mitochondrial membrane permeability changes and the decrease in protein levels of procaspases-8, -9 and -3 correlated with their apoptotic activity [27]. Choi et al. disclosed $\mathbf{6 1}$ induced apoptosis via activation of AMP-activated protein kinase in HT-29 colon cancer cells [28]. 

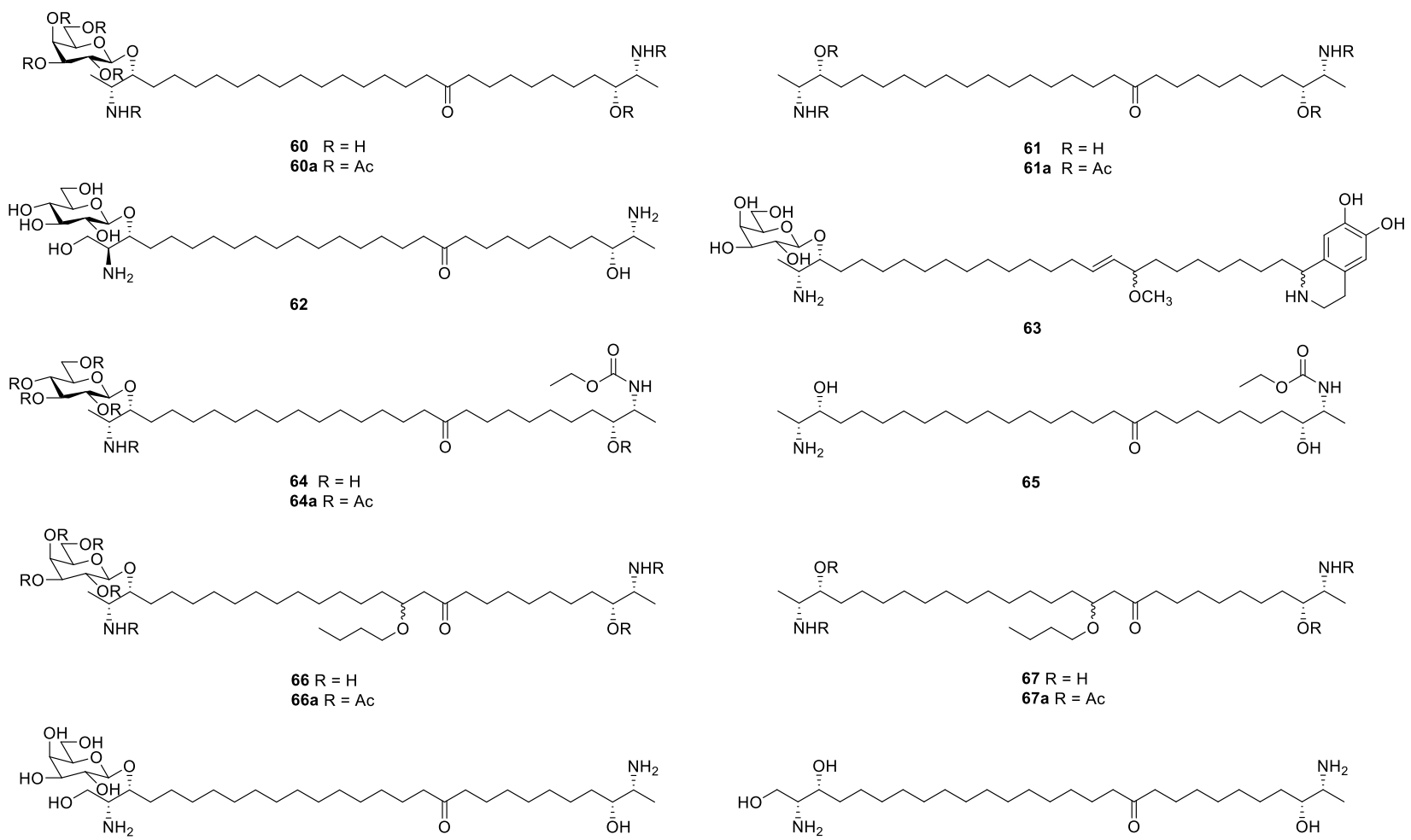

68

70
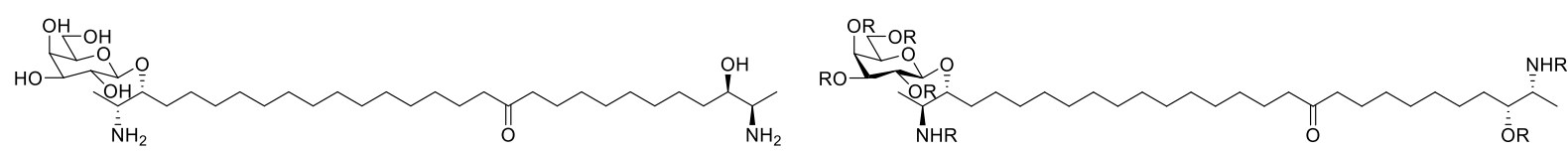

69
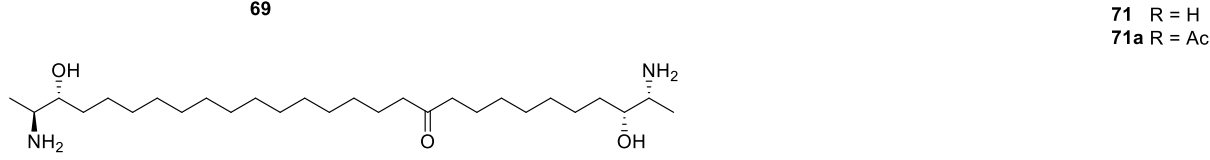

72

Figure 9. The chemical structures of sphingolipids 60-72.

Oceanapiside (62), a new bis- $\alpha, \omega$-amino alcohol glycoside from the marine sponge Oceanapia phillipensis collected in southern Australia, was reported by Molinski's group [29]. Soon after, the absolute stereochemistry of 62 was assigned $2 S, 3 R, 26 R, 27 R$ by analysis of CD spectra of its perbenzoate [30]. Compound 62 exhibited significant antifungal activity against the fluconazole-resistant yeast Candida glabrata with an MIC of $10 \mu \mathrm{g} / \mathrm{mL}$ in broth dilution experiments [29]. In addition, in vitro antifungal activity of a series of $\alpha, \omega$-bifunctionalized amino alcohols derived from $\mathbf{6 2}$ against $C$. glabrata was measured. The dimeric bifunctionalized lipids exhibited activity about 10-fold higher than D-sphingosine, which was a larger factor than expected from the simple additive effects of vicinal amino alcohol groups [31]. It may be worth pointing out that the application of a combined method including micromolarscale Baeyer-Villiger oxidation and LC-MS interpretation by Makarieva et al. led to a revision of the structure of 62 , in which the placement of the keto group should be at C-18 rather than C-11 [32]. Oceanalin A (63), a unique hybrid $\alpha, \omega$-bifunctionalized sphingoid tetrahydroisoquinoline $\beta$-glycoside, was discovered in the sponge Oceanapia sp. collected off the northwest coast of Australia. Its absolute structure $2 R, 3 R$ was elucidated by chemical correlation with the known rhizochalin 60 . Compound 63 exhibited in vitro antifungal activity against $C$. glabrata with an MIC of $30 \mu \mathrm{g} / \mathrm{mL}$ [33].

Rhizochalin A (64), the fourth representative of two-headed glycosphingolipids, was isolated as its peracetate (64a) from the sponge R. incrustata collected in the Seychelles 
Islands. Based on the chemical correlation, the absolute configuration $2 R, 3 R, 26 R, 27 R$ of 64 was determined to be the same as that of 60 . It might be worth pointing out that $64 a$ was the first example of a natural product among known sphingolipids, including the family of two-headed sphingolipids, that contained the rare $N$-alkyl carbamoyl group [34] Soon after, rhizochalinin A (65), the aglycone of rhizochalin A (64), was discovered in the former specimen. Compound 65 exhibited antileukemic activity against human leukemia THP-1 cells $\left(\mathrm{IC}_{50}=7.5 \mu \mathrm{M}\right)$ [35]. Two new, two-headed sphingolipid-like compounds, rhizochalin B (66) and its aglycone rhizochalinin B (67), were obtained as their corresponding peracetates $(66 a, 67 a)$ from the marine sponge Oceanapia sp. collected near the Scott reef (northwest of Australia). They differed from classical sphingolipids in the $\alpha, \omega$-position of the basic groups, resembling the polar ends of sphingoid bases, and often contained a terminal methyl group instead of the hydroxymethyl group. Notably, the stereochemistry of C-16 in compounds 66 and 67 remained unknown [36].

From the sponge $R$. incrustata collected in Madagascar, two new representatives of two-headed glycosphingolipids, rhizochalins $C$ (68) and D (69), were discovered. Based on the analysis of ${ }^{1} \mathrm{H}$ NMR data and CD spectra of their corresponding perbenzoates, the absolute configurations of $\mathbf{6 8}$ and $\mathbf{6 9}$ were assigned $2 R, 3 R, 26 R, 27 R$ and $2 R, 3 R, 27 R, 28 R$, respectively. In contrast to the regular $2 S, 3 R$-configuration found in normal sphingoid bases, 68 contained the rare $2 R, 3 R$ threo stereochemistry, while 69 possessed an odd-numbered C-29 hydrocarbon chain instead of C-28 found in canonical members of this series. It was a pity to find that rhizochalins $C(68)$ and $D(69)$ were not active $\left(E_{50}>150 \mu \mathrm{M}\right)$ against the fluconazole-resistant yeast $C$. glabrata [32]. In 2009, further study on this specimen led to a new antileukemic two-headed sphingolipid rhizochalinin $C(70)$, which was the aglycone of rhizochalin C (68). In the bioassay, 70 exhibited a cytotoxic effect against THP- $1\left(\mathrm{IC}_{50}=6.7 \mu \mathrm{M}\right)$ but was inactive against JB6 P+ Cl41 and HeLa cell lines [26]. Four years later, Molinski and his co-worker reported the first total synthesis of rhizochalinin C (70) [37].

Isorhizochalin (71), isolated as its peracetate (71a), was a minor bipolar sphingolipid of stereodivergent biogenesis from the $R$. incrustata. Similar to 60 , its absolute stereochemistry was elucidated as $2 S, 3 R, 26 R, 27 R$ by analysis of the $C D$ spectrum of its perbenzoate. $\mathbf{7 1}$ was a C-2 epimer of 60 with an erythro configuration at the glycosylated 2-amino-3-alkanol- $\alpha$ terminus, in contrast to the canonical threo configuration for other representatives of this structural group. In the bioassay, its aglycone, isorhizochalinin (72), showed cytotoxicity against human leukemia HL-60 and THP-1 cells with IC $_{50}$ values of 2.90 and $2.20 \mu \mathrm{M}$, respectively [38].

\subsection{Ceramides and Cerebrosides}

Chemical investigation on the sponge Oceanapia cf. tenuis collected in Woodin Channel, New Caledonia, led to a series of ceramides, named oceanapins A-F (73-78) (Figure 10), which were unique for branching at both the sphingosine and fatty-acid chains. A pair of Mosher's esters of the silyl ether derived from oceanapin D (76) was prepared, and the subsequent study on their NMR spectra revealed the $2^{\prime} S, 3^{\prime} R$ absolute configuration for the source compound 76 [39].

An inseparable mixture of ceramides 79 (Figure 10) containing nonbranched and isobranched $\mathrm{C}_{18}$ and $\mathrm{C}_{19}$-phytosphingosines acylated with nonhydroxylated fatty acids were disclosed in the ethanolic extract of the Australian sponge Oceanapia sp. This was the first report of natural iso- $\mathrm{C}_{19}$-phytosphingosine-containing ceramides. Although no bioactivity was reported for these ceramides, the crude ethanolic extract exhibited antimicrobial activities against $S$. aureus, B. subtilis, E. coli and C. albicans as well as cytotoxic properties against the Erlich murine carcinoma [40]. In another study on the Australian sponge Oceanapia sp., two cerebrosides $\mathbf{8 0}$ and $\mathbf{8 1}$ containing $\mathrm{N}$-acetylglucosamine were obtained [41]. 


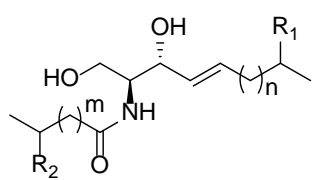

$73 \mathrm{n}=9 \mathrm{~m}=19 \mathrm{R}_{1}=\mathrm{HR}_{2}=\mathrm{Me}$ $74 \mathrm{n}=9 \mathrm{~m}=19 \mathrm{R}_{1}=\mathrm{R}_{2}=\mathrm{Me}$ $75 \mathrm{n}=9 \mathrm{~m}=20 \mathrm{R}_{1}=$ Me $\mathrm{R}_{2}=\mathrm{H}$ $76 \mathrm{n}=10 \mathrm{~m}=19 \mathrm{R}_{1}=\mathrm{R}_{2}=\mathrm{Me}$ $77 \mathrm{n}=10 \mathrm{~m}=19 \mathrm{R}_{1}=\mathrm{Et} \mathrm{R}_{2}=\mathrm{H}$ $78 \mathrm{n}=10 \mathrm{~m}=19 \mathrm{R}_{1}=\mathrm{Et} \mathrm{R}_{2}=\mathrm{Me}$

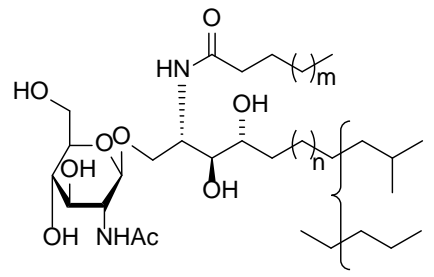

$80 m=12,13,14 n=8,9$

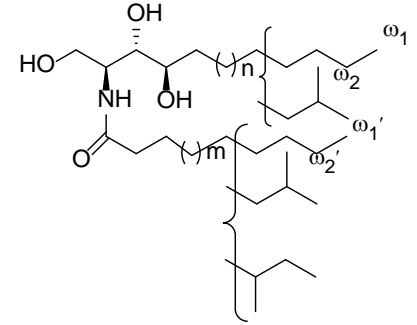

$79 n=8,9 m=8-10,14-20$

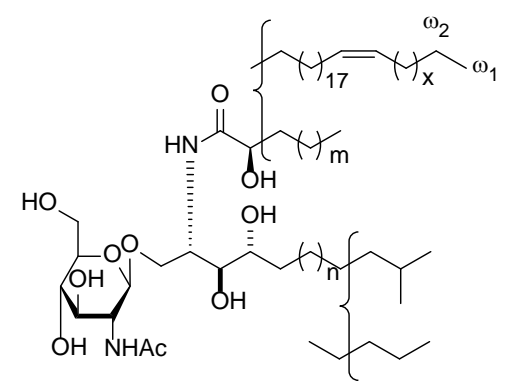

$81 \mathrm{~m}=20,21,22 n=6,7,8 x=2,4$

Figure 10. The chemical structures of ceramides and cerebrosides 73-81.

\subsection{Dithiocyanates}

The aqueous ethanol extract of an Oceanapia sp. collected off the northern Rottnest Shelf, Australia, displayed potent nematocidal activity against the commercial livestock parasite Haemonchus contortus ( $\mathrm{LD}_{99}=135 \mu \mathrm{g} / \mathrm{mL}$ ). Bioassay-directed fractionation yielded the bioactive principle component thiocyanatin $\mathrm{A}(82)\left(\mathrm{LD}_{99}=1.3 \mu \mathrm{g} / \mathrm{mL}\right)$, together with the inseparable pairs of inactive analogues thiocyanatins $B(83)$ and $C(84), \beta$-methyl branched bisthiocyanates thiocyanatins D1 (85) and D2 (86) (LD99 $=3.1 \mu \mathrm{g} / \mathrm{mL})$ and thiocarbamate thiocyanates thiocyanatins E1 (87) and E2 (88) (Figure 11). Their structure assignments were confirmed by chemical synthesis and comparisons with synthetic model compounds. However, the stereochemical character of C-8 in 82 and 85-88 remained unknown. In addition to featuring an unprecedented dithiocyanate functionality, thiocyanatins 82-88 possessed an unusual 1,16-difunctionalized $n$-hexadecane carbon skeleton and were revealed as a hitherto unknown class of nematocidal agent. Preliminary structure-activity relationship investigations highlighted the importance of both the secondary -OH and -SCN functionalities and the influence of chain length on nematocidal activity $[42,43]$.

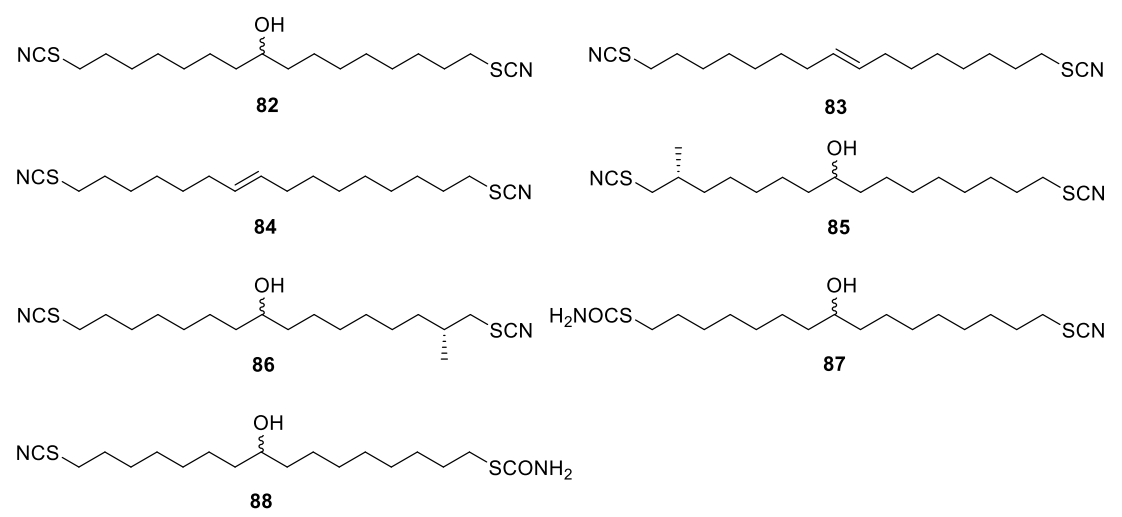

Figure 11. The chemical structures of dithiocyanates 82-88.

\subsection{Polyacetylenes}

The study on the Indonesian sponge Oceanapia sp. led to three bromo-substituted polyunsaturated $C_{16}$ fatty acids $(7 E, 13 E, 15 Z)-14,16$-dibromohexadeca-7,13,15-trien-5-ynoic 
acid (89), (5Z,7E,9E,13E,15Z)-6,14,16-tribromohexadeca-5,7,9,13,15-pentaenoic acid (90) and $(7 E, 9 E, 13 E, 15 Z)-14,16$-dibromohexadeca-7,9,13,15-tetraen-5-ynoic acid (91) (Figure 12). Their common structural feature was a $(13 E, 15 Z)-14,16$-dibromo-diene terminus. They differed in their C-5 to C-10 segments in unsaturation and halogenation. The cytotoxicity bioassay was tested on the mixture, since compounds 89-91 were unstable when pure, which showed only weak cytotoxicity $(2+$ at $10 \mu \mathrm{g} / \mathrm{mL})$ against KB cells. Compound 91 showed mild antimicrobial activity against Gram-positive bacteria [44]. A $\mathrm{C}_{14}$ acetylenic acid 7E,11E-tetradecadiene-5,9-diynoic acid (92) was isolated as antimicrobial principle from the sponge of Oceanapia sp. collected in Kamagi Bay on the Sada Peninsula. This compound was the first example of a midchain acetylenic acid without a bromine atom, as well as the first reported member of a marine acetylene containing a $\mathrm{CH}=\mathrm{CH}-\mathrm{C} \equiv \mathrm{C}-$ $\mathrm{CH}=\mathrm{CH}-\mathrm{C} \equiv \mathrm{C}$ unit. In the bioassay, 92 exhibited some selectivity in antimicrobial activity. It was moderately active against four mutants of Saccharomyces cerevisiae and C. albicans but was inactive against Penicillium chrysogenum and Mortierella ramanniana. It also exhibited inhibitory effects against both Gram-positive and Gram-negative bacteria [45].<smiles>O=C(O)CCCC#C/C=C/CCCCC/C=C(Br)\C=C/Br</smiles>

89<smiles>O=C(O)CCCC#C/C=C/C=C/CC/C=C(Br)\C=C/Br</smiles><smiles>O=C(O)CCC/C=C(Br)/C=C/C=C/CC/C=C(Br)\C=C/Br</smiles>

90<smiles>C/C=C/CC#CCCC#CCCCC(=O)O</smiles>

92

Figure 12. The chemical structures of polyacetylenes 89-92.

\section{Sterols}

The sterol profile of a north-western Australian marine sponge Oceanapia sp. was reported for the first time by Stonik et al. It contained stanols (93-102) and $\triangle^{5}$-sterols (103-105) with 24R-24,25-methylene-5 $\alpha$-cholestan-3 $\beta$-ol (99) (Figure 13) as the main constituent [46]. Notably, the structure of the major cyclopropane-containing stanol 99 was firstly obtained from Rhizochalina (= Oceanapia) incrustata off the coast of the Seychelles Islands [47]. In the investigation on the marine sponge O. sagittaria from the Gulf of Thailand, 24 $\alpha$-methylcholestanol (106) was isolated [8].

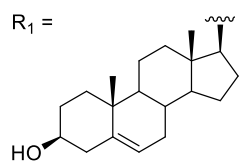<smiles>[R2]C(C)/C=C/C(C)C</smiles>

93<smiles>[R]C(C)/C=C/C(C)C(C)C</smiles>

97<smiles>[R]C(C)/C=C/C(CC)C(C)C</smiles>

101<smiles>[R]C(C)CCC(CC)C(C)C</smiles><smiles>[R2]C(C)C=CC(C)CC</smiles>

94<smiles>[R]C(C)CCC(=C)C(C)C</smiles>

98<smiles>[R]C(C)CCC(CC)C(C)C</smiles><smiles>CC1CCC2C3CCC4CC(O)CCC4CC3CCC12C</smiles><smiles>[R2]C(C)/C=C/CC(C)C</smiles>

95<smiles>[R]C(C)CCCC(C)(C)C</smiles>

99<smiles>[R]C(C)CCCC(C)C</smiles>

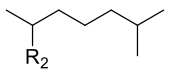

96<smiles>[R]C(C)/C=C(\C)C(C)C(C)C</smiles>

100<smiles>[R]C(C)/C=C/C(C)C(C)C</smiles><smiles>[R]C(C)CCC(C)C(C)C</smiles>

Figure 13. The chemical structures of sterols 93-106. 


\section{Other Miscellaneous}

The organic extract from the Caribbean O. bartschi was shown to contain the antibiotic diterpene ambliol A (107) (Figure 14) [18]. Three aromatic compounds, $p$-hydroxybenzaldehyde (108), $p$-hydroxybenzoic acid (109) and phenylacetic acid (110), were found in the sponge O. sagittaria collected from the Gulf of Thailand [8]<smiles>CC(=CCCc1ccoc1)CCC1C(C)(C)CCCC1(C)O</smiles>

107<smiles>O=Cc1ccc(O)cc1</smiles>

108<smiles>O=C(O)c1ccc(O)cc1</smiles>

109<smiles>O=C(O)Cc1ccccc1</smiles>

110

Figure 14. The chemical structures of miscellaneous 107-110.

\section{Chemical Synthesis of Four Secondary Metabolites}

\subsection{Synthesis of $( \pm)$-Phloeodictine A1 (( \pm$)-21)$}

The $( \pm)$-phloeodictine A1 ( \pm$)$-21) was synthesized by a convergent route by Snider et al. as shown in Scheme 1 [15]. Furan-maleic anhydride Diels-Alder adduct 111 was used as the starting material for the 6-hydroxy-1,2,3,4-tetrahydropyrrolo[1,2-a]pyrimidinium skeleton. Imide 112 was obtained from 111 via a reaction with 3-aminopropanol, which was quantitatively converted to mesylate 113. The reaction of $\mathbf{1 1 3}$ with $\mathrm{NaN}_{3}$ provided azide 114. The Eguchi aza-Wittig reaction of 114 afforded $\mathbf{1 1 4 b}$, which was followed by a thermal retro Diels-Alder reaction to liberate 115. The addition of Grignard reagents to 115 produced 116a. Washing a $\mathrm{CH}_{2} \mathrm{Cl}_{2}$ solution of 116a with $1 \mathrm{M} \mathrm{NaOH}$ solution afforded 116b. In addition, Snider et al. selected a convergent route for iodide $\mathbf{1 2 0}$ containing a protected guanidine on the other end of the chain. The approach was that the reaction of 117 with the appropriate $\omega$-amino-1-alkanol in THF gave 118, then mesylation and successive displacement with iodide afforded 120. Finally, alkylation of 116b with 120 afforded 121, and subsequent deprotection of $\mathbf{1 2 1}$ completed the synthesis of 21.

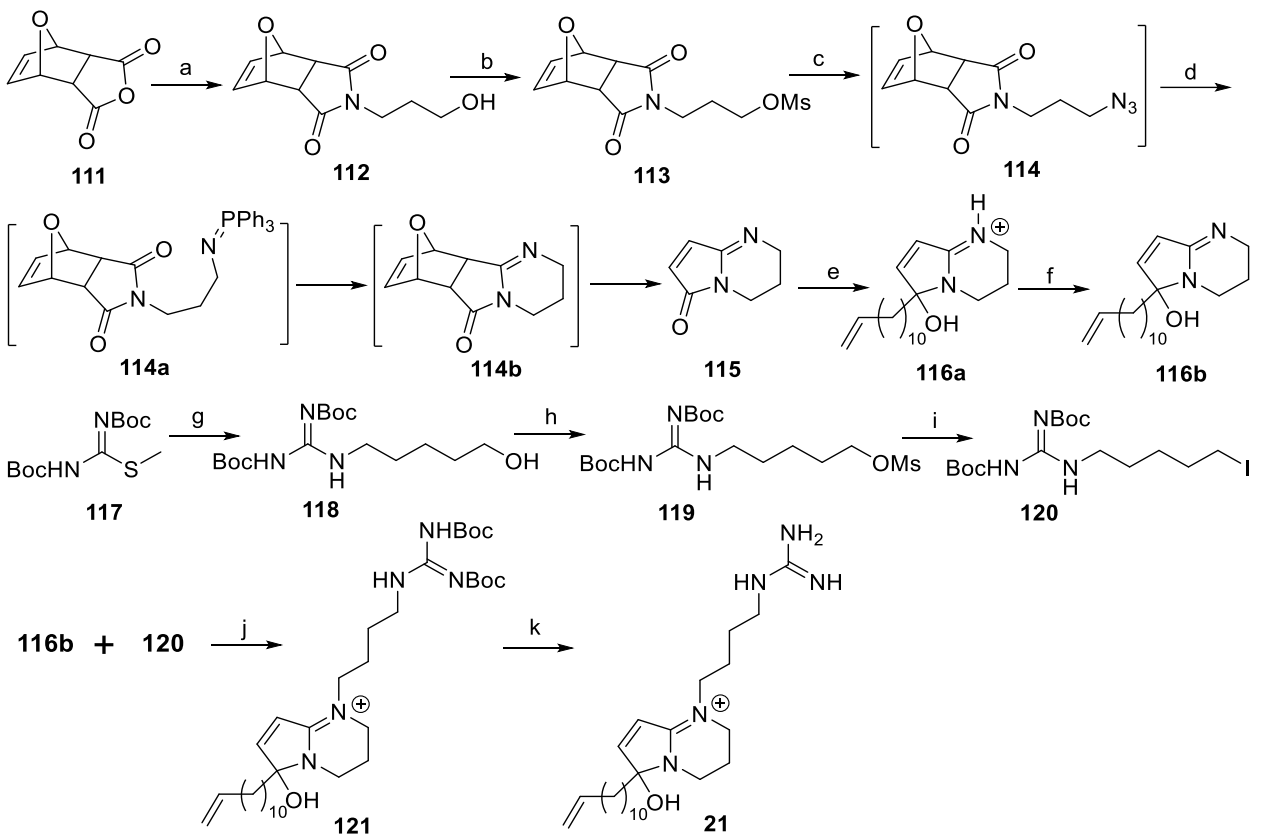

Scheme 1. Synthetic route of phloeodictine A1 (21). Reagents: (a) 3-aminopropanol, $\mathrm{MeOH}, 56{ }^{\circ} \mathrm{C}$, 3 d; (b) $\mathrm{Et}_{3} \mathrm{~N}, \mathrm{MsCl}, \mathrm{CH}_{2} \mathrm{Cl}_{2}, 0{ }^{\circ} \mathrm{C}$; (c) $\mathrm{NaN}_{3}, \mathrm{DMF}, 25{ }^{\circ} \mathrm{C}, 14 \mathrm{~h}$; (d) $\mathrm{Ph}_{3} \mathrm{P}$, toluene, reflux $4 \mathrm{~h}$; (e) 11-dodecenyl magnesium bromide, $\mathrm{CeCl}_{3}, \mathrm{THF}, 0^{\circ} \mathrm{C}$; (f) $1 \mathrm{M} \mathrm{NaOH}$; (g) $\omega$-amino-1-pentanol, THF, $50{ }^{\circ} \mathrm{C}, 2 \mathrm{~h}$; (h) $\mathrm{MsCl}, \mathrm{Et}_{3} \mathrm{~N}, \mathrm{CH}_{2} \mathrm{Cl}_{2}, 0^{\circ} \mathrm{C}$ (i) $\mathrm{NaI}, \mathrm{NaHCO}_{3}$, acetone, reflux, $4 \mathrm{~h}$; (j) DMSO-d ${ }_{6}, 25^{\circ} \mathrm{C}$, $24 \mathrm{~h}$; (k) TFA $/ \mathrm{CH}_{2} \mathrm{Cl}_{2}(1: 1), 2 \mathrm{~h}$. 


\subsection{Synthesis of 6-Br-8-keto-conicamin A (55)}

In Crews et al.'s work, indole-3-carboxaldehyde $\mathbf{1 2 2}$ was used as the starting material as outlined in Scheme 2 [19]. First, 122 was esterified to yield its cyanohydrin silylether 123, then the oxidation of 123 via DDQ followed by hydrogenation led to keto-tryptamine synthon 125. Bromination of $\mathbf{1 2 5}$ proceeded in a straightforward fashion, producing the bromo-keto-tryptamine 126. The final step involved the methylation of $\mathbf{1 2 6}$ to afford 6-Br-8-keto-conicamin A (55).

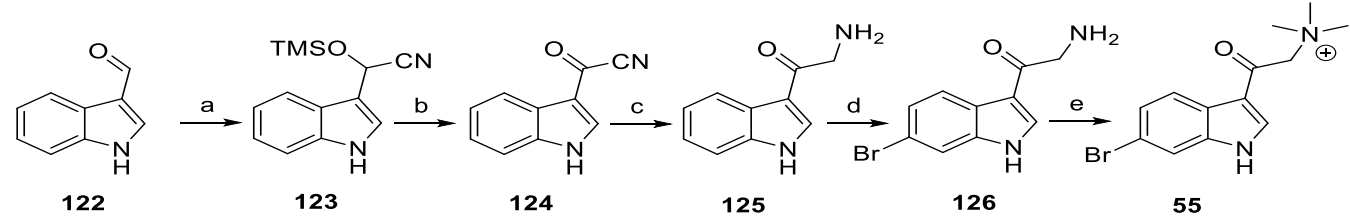

Scheme 2. Synthetic route of 6-Br-8-keto-conicamin A (55). Reagents: (a): TMSCN, DME, reflux $1.5 \mathrm{~h}$, cool; (b): DDQ (dropwise), Dioxane, rt; (c): $\mathrm{H}_{2}, \mathrm{Pd} / \mathrm{C}, \mathrm{AcOH}$; (d): $\mathrm{Br}_{2}, \mathrm{rt} 24$ h, $\mathrm{HCOOH}: \mathrm{CH}_{3} \mathrm{COOH}$ (1:1); (e): Mel, rt 16 h, $\mathrm{MeOH}, \mathrm{KHCO}_{3}$.

\subsection{Synthesis of Rhizochalinin C (70)}

Molinski et al. disclosed an optimized procedure for rapid diastereoselective access to L-threo-sphingoid base synthons, using a remarkable one-pot conversion of unprotected D-glucosamine into useful D-serine synthons based on $\operatorname{~In}^{0}$-mediated allylation. This method was successfully applied to rhizochalinin C (70), which was elaborated as shown in Scheme 3 [37].

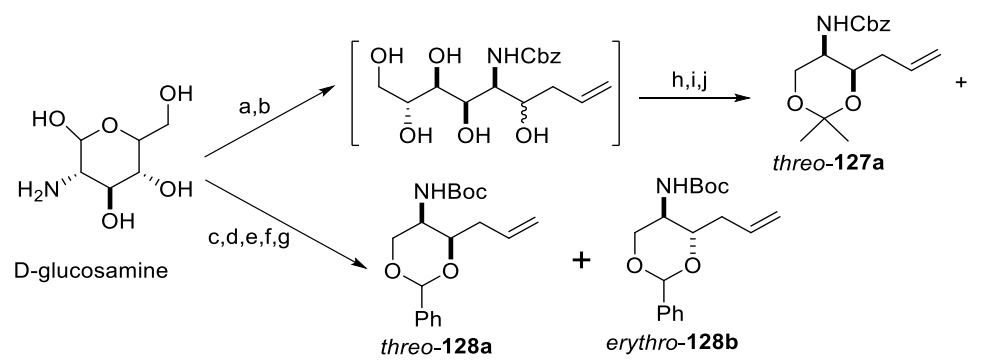<smiles>C=CCC1OC([18O])([18O])OCC1N[N+](=O)[O-]</smiles>

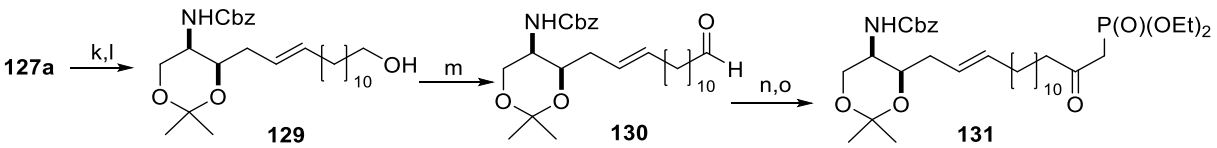<smiles></smiles>

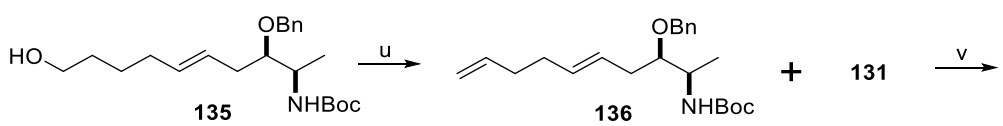<smiles>CC(N)CC(O)C(O)CC(=O)CCC(=O)CCCCCCCC(O)C(C)N</smiles>

Scheme 3. Synthetic route of rhizochalinin C (70). Reagents: (a) In ${ }^{0}$, allyl bromide, 1,4-dioxane: $\mathrm{H}_{2} \mathrm{O}$ (3:1), $100{ }^{\circ} \mathrm{C}$; (b) $\mathrm{CBz}_{-} \mathrm{Cl}, \mathrm{NaHCO}_{3}$ (aq.); (c) In ${ }^{0}$, allyl bromide, 1,4-dioxane: $\mathrm{H}_{2} \mathrm{O}$ (3:1), $100{ }^{\circ} \mathrm{C}$; (d) (Boc) ${ }_{2} \mathrm{O}, \mathrm{NaHCO}_{3}$ (aq.); (e) $\mathrm{NaIO}_{4}, \mathrm{H}_{2} \mathrm{O}$; (f) $\mathrm{NaBH}_{4}, \mathrm{MeOH}$; (g) $\mathrm{CSA},(\mathrm{MeO})_{2} \mathrm{C}\left(\mathrm{CH}_{3}\right)_{2}$; (h) $\mathrm{NaIO}_{4}$, $\mathrm{H}_{2} \mathrm{O}$; (i) $\mathrm{NaBH}_{4}, \mathrm{MeOH}$; (j) $\mathrm{CSA},(\mathrm{MeO})_{2} \mathrm{C}\left(\mathrm{CH}_{3}\right)_{2}$; (k) tetradec-13-enyl acetate, Grubbs II catalyst, $\mathrm{CH}_{2} \mathrm{Cl}_{2}$, reflux; (l) NaOMe, $\mathrm{MeOH}$; (m) DMP, $\mathrm{CH}_{2} \mathrm{Cl}_{2}$; (n) (EtO) ${ }_{2} \mathrm{P}(\mathrm{O}) \mathrm{CH}_{3}, \mathrm{n}-\mathrm{BuLi}, \mathrm{THF},-78{ }^{\circ} \mathrm{C}$; (o) $\mathrm{DMP}, \mathrm{CH}_{2} \mathrm{Cl}_{2}$; (p) $\mathrm{AlH}_{3}, \mathrm{Et}_{2} \mathrm{O}, 0^{\circ} \mathrm{C}$; (q) PhSSPh, n-Bu 3 P, THF; (r) 4-penten-1-ylacetate, Grubbs II cat., $\mathrm{CH}_{2} \mathrm{Cl}_{2}$, reflux; (s) NaOMe, $\mathrm{MeOH}$; (t) $\mathrm{Ra}-\mathrm{Ni}$; (u) DMP, $\mathrm{CH}_{2} \mathrm{Cl}_{2}$; (v) $\mathrm{Ba}(\mathrm{OH})_{2}$, wet THF; (w) $10 \mathrm{M}$ $\mathrm{HCl}, \mathrm{MeOH}, \mathrm{H}_{2}, 2 \mathrm{~atm}, \mathrm{Pd}-\mathrm{C}$. 
The allyl-substituted compounds 127a and 128a that were procured from the Barbier allylation of D-glucosamine were followed by differential protections of $\mathrm{NH}_{2}$ and $\mathrm{OH}$ groups. 127a was subjected to olefin cross-metathesis with tetradec-13-enyl acetate, after methanolysis, to provide the primary alcohol 129. Then, Dess-Martin oxidation of 129 led to the corresponding aldehyde 130, which was followed by the addition of the anion derived from diethyl methylphosphonate, and oxidation delivered the $\beta$-ketophosphonate 131. The alcohol 132, the reduction product of $\mathbf{1 2 8 a}$, was transformed into the phenylthio ether to give 133. Olefin cross-metathesis of 133 with 4-penten-1-yl acetate followed by methanolysis yielded the primary alcohol 134. Reduction of 134 delivered protected threo2-amino-3-alkanol 135, and the subsequent oxidation of 135 led to the aldehyde 136. The Horner-Emmons-Wadsworth reaction of aldehyde 131 and 136 under Paterson conditions gave the $\alpha, \beta$-unsaturated ketone 137, which was deprotected to yield 70 .

\subsection{Synthesis of Thiocyanatin A (82)}

Capon et al. reported the seven-step total synthesis of thiocyanatin $\mathrm{A}(\mathbf{8 2})$ starting from 8-bromooctanoic acid (138) [43]. The esterification of 8-bromooctanoic acid (138) yielded its methyl ester 139, which was converted to the Wittig salt 140. The following one-pot oxidation-Wittig coupling afforded the olefin-diester 141. The triol 142 was obtained by the epoxidation of 141 with $m$-CPBA and the successive reduction of the corresponding epoxide with $\mathrm{LiAlH}_{4}$. Treatment of $\mathbf{1 4 2}$ with $\mathrm{TsCl}$ gave the ditosylate 143. Finally, the displacement of the tosylate groups by thiocyanate afforded racemic thiocyanatin A (82) as outlined in Scheme 4.

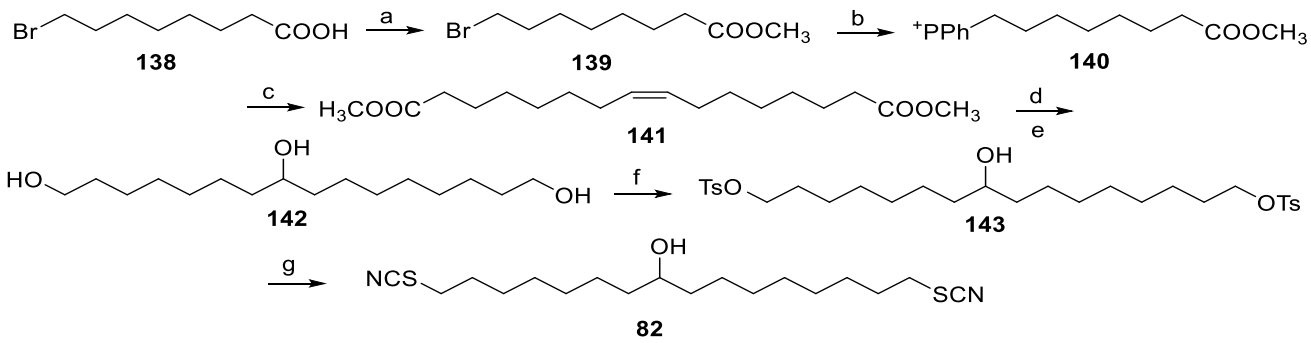

Scheme 4. Synthetic route of thiocyanatin A (82). Reagents: (a) $\mathrm{H}_{2} \mathrm{SO}_{4}, \mathrm{MeOH}$, reflux $16 \mathrm{~h}$; (b) $\mathrm{PPh}_{3}$, MeCN, reflux 16 h; (c) NaHMDS, THF/DMPU, $\mathrm{O}_{2}, 60{ }^{\circ} \mathrm{C}, 16 \mathrm{~h}$; (d) m-CPBA, $\mathrm{CH}_{2} \mathrm{Cl}_{2}$, rt, 16 h; (e) $\mathrm{LiAlH}_{4}$, reflux $20 \mathrm{~h}$; (f) p-TsCl, $\mathrm{CH}_{2} \mathrm{Cl}_{2}, \mathrm{DMAP}_{\mathrm{NEt}}, \mathrm{rt}, 32 \mathrm{~h}$; (g) $\mathrm{KSCN}, \mathrm{THF}$, reflux $16 \mathrm{~h}$.

\section{Conclusions and Perspectives}

A huge library of secondary metabolites was reported from the sponges of the genus Oceanapia, with up to 110 compounds with unique structures, from 1989 to July 2019. More than eight species of Oceanapia sponges have been chemically investigated, including Oeanapia sagittaria, Oceanapia fistulosa, Oceanapia bartschi, Phloeodictyon sp., Rhizochalina incrustata, Oceanapia ramsayi, Oceanapia phillipensis, Oceanupia cf. tenuis and Oceanapia sp. The chemical structures were classified as alkaloids, lipids, sterols and other miscellaneous. Among them, alkaloids were encountered most frequently. These compounds exhibited diverse biological properties ranging from insecticidal, cytotoxic and antifeedant to antibacterial. Their unique structures and promising bioactivities have attracted a great deal of attention from synthetic chemists for their total synthesis.

Author Contributions: Conceptualization, L.-F.L.; investigation, M.-J.X., L.-J.Z., J.-K.C. and Q.B.; writing - original draft preparation, M.-J.X. and L.-F.L.; writing—review and editing, L.-F.L.; funding acquisition, L.-F.L. All authors have read and agreed to the published version of the manuscript.

Funding: This research was funded by the National Natural Science Foundation of China (No. 41876194).

Conflicts of Interest: The author declares no conflict of interest. 


\section{References}

1. Jiménez, C. Marine natural products in medicinal chemistry. ACS Med. Chem. Lett. 2018, 9, 959-961. [CrossRef] [PubMed]

2. Carroll, A.R.; Copp, B.R.; Davis, R.A.; Keyzers, R.A.; Prinsep, M.R. Marine natural products. Nat. Prod. Rep. 2019 , 36, 122-173. [CrossRef] [PubMed]

3. Desqueyroux-Faúndez, R.; Valentine, C. Family Phloeodictyidae Carter, 1882. In Systema Porifera: A Guide to the Classification of Sponges; Hooper, J.N.A., Van Soest, R.W.M., Willenz, P., Eds.; Springer: Boston, MA, USA, 2002; pp. 893-905.

4. Salomon, C.E.; Faulkner, D.J. Sagitol, a pyridoacridine alkaloid from the sponge Oceanapia sagittaria. Tetrahedron Lett. 1996, 37, 9147-9148. [CrossRef]

5. Eder, C.; Schupp, P.; Proksch, P.; Wray, V.; Steube, K.; Müller, C.E.; Frobenius, W.; Herderich, A.M.; van Soest, R.W.M. Bioactive pyridoacridine alkaloids from the Micronesian sponge Oceanapia sp. J. Nat. Prod. 1998, 61, 301-305. [CrossRef] [PubMed]

6. Gunawardana, G.P.; Koehn, F.E.; Lee, A.Y.; Clardy, J.; He, H.Y.; Faulkner, D.J. Pyridoacridine alkaloids from deep-water marine sponges of the family Pachastrellidae: Structure revision of dercitin and related compounds and correlation with the kuanoniamines. J. Org. Chem. 1992, 57, 1523-1526. [CrossRef]

7. Schupp, P.; Eder, C.; Paul, V.; Proksch, P. Distribution of secondary metabolites in the sponge Oceanapia sp. and its ecological implications. Mar. Biol. 1999, 135, 573-580. [CrossRef]

8. Kijjoa, A.; Wattanadilok, R.; Campos, N.; Herz, W.; Nascimento, M.S.J.; Pinto, M. Anticancer activity evaluation of kuanoniamines A and C isolated from the marine sponge Oceanapia sagittaria, collected from the Gulf of Thailand. Mar. Drugs 2007, 5, 6-22. [CrossRef]

9. Carroll, A.R.; Ngo, A.; Quinn, R.J.; Redburn, J.; Hooper, J.N.A. Petrosamine B, an inhibitor of the Helicobacter pylori enzyme aspartyl semialdehyde dehydrogenase from the Australian sponge Oceanapia sp. J. Nat. Prod. 2005, 68, 804-806. [CrossRef]

10. Ibrahim, S.R.M.; Mohamed, G.A.; Elkhayat, E.S.; Fouad, M.A.; Proksch, P. Sagitol C, a new cytotoxic pyridoacridine alkaloid from the sponge Oceanapia sp. Bull. Fac. Pharm. Cairo Univ. 2013, 51, 229-232. [CrossRef]

11. Singh, K.S.; Das, B.; Naik, C.G. Quinolizidines alkaloids: Petrosin and xestospongins from the sponge Oceanapia sp. J. Chem. Sci. 2011, 123, 601-607. [CrossRef]

12. Boyd, K.G.; Harper, M.K.; Faulkner, D.J. Oceanapamine, a sesquiterpene alkaloid from the Philippine sponge Oceanapia sp. J. Nat. Prod. 1995, 58, 302-305. [CrossRef] [PubMed]

13. Kourany-Lefoll, E.; Pais, M.; Sevenet, T.; Guittet, E.; Montagnac, A.; Fontaine, C.; Guenard, D.; Adeline, M.T.; Debitus, C. Phloeodictines A and B: New antibacterial and cytotoxic bicyclic amidinium salts from the New Caledonian sponge, Phloeodictyon sp. J. Org. Chem. 1992, 57, 3832-3835. [CrossRef]

14. Kourany-Lefoll, E.; Laprévote, O.; Sévenet, T.; Montagnac, A.; Païs, M.; Debitus, C. Phloeodictines A1-A7 and C1-C2, antibiotic and cytotoxic guanidine alkaloids from the New Caledonian sponge, Phloeodictyon sp. Tetrahedron 1994, 50, 3415-3426. [CrossRef]

15. Neubert, B.J.; Snider, B.B. Synthesis of ( \pm -phloeodictine A1. Org. Lett. 2003, 5, 765-768. [CrossRef]

16. Mancini, I.; Guella, G.; Sauvain, M.; Debitus, C.; Duigou, A.-G.; Ausseil, F.; Menou, J.-L.; Pietra, F. New 1,2,3,4tetrahydropyrrolo[1,2-a]pyrimidinium alkaloids (phloeodictynes) from the New Caledonian shallow-water haplosclerid sponge Oceanapia fistulosa. Structural elucidation from mainly LC-tandem-MS-soft-ionization techniques and discovery of antiplasmodial activity. Org. Biomol. Chem. 2004, 2, 783-787. [CrossRef]

17. Nicholas, G.M.; Newton, G.L.; Fahey, R.C.; Bewley, C.A. Novel bromotyrosine alkaloids: Inhibitors of mycothiol S-conjugate amidase. Org. Lett. 2001, 3, 1543-1545. [CrossRef]

18. Cafieri, F.; Fattorusso, E.; Mahajnah, Y.; Mangoni, A. 6-Bromo-5-hydroxy-3-indolecarboxyaldehyde from the Caribbean sponge Oceanapia bartschi. Z. Naturforsch. B-J. Chem. Sci. 1993, 48, 1408-1410. [CrossRef]

19. Lorig-Roach, N.; Hamkins-Indik, F.; Johnson, T.A.; Tenney, K.; Valeriote, F.A.; Crews, P. The potential of achiral sponge-derived and synthetic bromoindoles as selective cytotoxins against PANC-1 tumor cells. Tetrahedron 2018, 74, 217-223. [CrossRef]

20. Venkateswarlu, Y.; Reddy, N.S.; Ramesh, P.; Rao, J.V. Coixol: A bioactive principle from a marine sponge Oceanapia sp. Biochem. Syst. Ecol. 1999, 27, 519-520. [CrossRef]

21. Nakamukai, S.; Ise, Y.; Ohtsuka, S.; Okada, S.; Matsunaga, S. Isolation and identification of N6-isopentenyladenosine as the cytotoxic constituent of a marine sponge Oceanapia sp. Biosci. Biotechnol. Biochem. 2019, 83, 1985-1988. [CrossRef]

22. Makarieva, T.N.; Denisenko, V.A.; Stonik, V.A.; Milgrom, Y.M.; Rashkes, Y.V. Rhizochalin, a novel secondary metabolite of mixed biosynthesis from the sponge Rhizochalina incrustata. Tetrahedron Lett. 1989, 30, 6581-6584. [CrossRef]

23. Popov, A.M.; Makarieva, T.N.; Stonik, V.A. Membrane activity of rhizochalin isolated from Rhizochalina incrustata. Biofizika 1990, 35, 883-884. [PubMed]

24. Molinski, T.F.; Makarieva, T.N.; Stonik, V.A. (-)-Rhizochalin is a dimeric enantiomorphic (2R)-sphingolipid: Absolute configuration of pseudo-C2v-symmetric bis-2-amino-3-alkanols by CD. Angew. Chem. Int. Ed. 2000, 39, 4076-4079. [CrossRef]

25. Bensemhoun, J.; Bombarda, I.; Aknin, M.; Faure, R.; Vacelet, J.; Gaydou, E.M. Marine bifunctional sphingolipids from the sponge Oceanapia ramsayi. Molecules 2008, 13, 772-778. [CrossRef] [PubMed]

26. Fedorov, S.N.; Makarieva, T.N.; Guzii, A.G.; Shubina, L.K.; Kwak, J.Y.; Stonik, V.A. Marine two-headed sphingolipid-like compound rhizochalin inhibits EGF-induced transformation of JB6 P+ Cl41 cells. Lipids 2009, 44, 777-785. [CrossRef] [PubMed]

27. Jin, J.-O.; Shastina, V.; Park, J.-I.; Han, J.-Y.; Makarieva, T.; Fedorov, S.; Rasskazov, V.; Stonik, V.; Kwak, J.-Y. Differential induction of apoptosis of leukemic cells by rhizochalin, two headed sphingolipids from sponge and its derivatives. Biol. Pharm. Bull. 2009, 32, 955-962. [CrossRef] 
28. Khanal, P.; Kang, B.S.; Yun, H.J.; Cho, H.-G.; Makarieva, T.N.; Choi, H.S. Aglycon of rhizochalin from the Rhizochalina incrustata induces apoptosis via activation of AMP-activated protein kinase in HT-29 colon cancer cells. Biol. Pharm. Bull. 2011, 34, 1553-1558. [CrossRef]

29. Nicholas, G.M.; Hong, T.W.; Molinski, T.F.; Lerch, M.L.; Cancilla, M.T.; Lebrilla, C.B. Oceanapiside, an antifungal bis- $\alpha, \omega$-amino alcohol glycoside from the marine sponge Oceanapia phillipensis. J. Nat. Prod. 1999, 62, 1678-1681. [CrossRef]

30. Nicholas, G.M.; Molinski, T.F. Enantiodivergent biosynthesis of the dimeric sphingolipid oceanapiside from the marine sponge Oceanapia phillipensis. Determination of remote stereochemistry. J. Am. Chem. Soc. 2000, 122, 4011-4019. [CrossRef]

31. Nicholas, G.M.; Li, R.; MacMillan, J.B.; Molinski, T.F. Antifungal activity of bifunctional sphingolipids. intramolecular synergism within long-chain $\alpha, w$-bis-aminoalcohols. Bioorganic Med. Chem. Lett. 2002, 12, 2159-2162. [CrossRef]

32. Makarieva, T.N.; Dmitrenok, P.S.; Zakharenko, A.M.; Denisenko, V.A.; Guzii, A.G.; Li, R.; Skepper, C.K.; Molinski, T.F.; Stonik, V.A. Rhizochalins $\mathrm{C}$ and $\mathrm{D}$ from the sponge Rhizochalina incrustata. A rare threo-sphingolipid and a facile method for determination of the carbonyl position in $\alpha, \omega$-bifunctionalized ketosphingolipids. J. Nat. Prod. 2007, 70, 1991-1998. [CrossRef] [PubMed]

33. Makarieva, T.N.; Denisenko, V.A.; Dmitrenok, P.S.; Guzii, A.G.; Santalova, E.A.; Stonik, V.A.; MacMillan, J.B.; Molinski, T.F. Oceanalin A, a hybrid $\alpha, \omega$-bifunctionalized sphingoid tetrahydroisoquinoline $\beta$-glycoside from the marine sponge Oceanapia sp. Org. Lett. 2005, 7, 2897-2900. [CrossRef]

34. Makarieva, T.N.; Guzii, A.G.; Denisenko, V.A.; Dmitrenok, P.S.; Santalova, E.A.; Pokanevich, E.V.; Molinski, T.F.; Stonik, V.A Rhizochalin A, a novel two-headed sphingolipid from the sponge Rhizochalina incrustata. J. Nat. Prod. 2005, 68, 255-257. [CrossRef] [PubMed]

35. Makarieva, T.N.; Zakharenko, A.M.; Denisenko, V.A.; Dmitrenok, P.S.; Guzii, A.G.; Shubina, L.K.; Kapustina, I.I.; Fedorov, S.N. Rhizochalinin A, a new antileukemic two-headed sphingolipid from the sponge Rhizochalina incrustata. Chem. Nat. Compd. 2007, 43, 468-469. [CrossRef]

36. Makarieva, T.N.; Guzii, A.G.; Denisenko, V.A.; Dmitrenok, P.S.; Stonik, V.A. New two-headed sphingolipid-like compounds from the marine sponge Oceanapia sp. Russ. Chem. Bull. 2008, 57, 669-673. [CrossRef]

37. Ko, J.; Molinski, T.F. D-Glucosamine-derived synthons for assembly of L-threo-sphingoid bases. Total synthesis of rhizochalinin C. J. Org. Chem. 2012, 78, 498-505. [CrossRef]

38. Makarieva, T.N.; Zakharenko, A.M.; Dmitrenok, P.S.; Guzii, A.G.; Denisenko, V.A.; Savina, A.S.; Dalisay, D.S.; Molinski, T.F.; Stonik, V.A. Isorhizochalin: A minor unprecedented bipolar sphingolipid of stereodivergent biogenesis from the Rhizochalina incrustata. Lipids 2009, 44, 1155-1162. [CrossRef]

39. Mancini, I.; Guella, G.; Pietra, F.; Debitus, C. Oceanapins A-F, unique branched ceramides isolated from the haplosclerid sponge Oceanapia cf. tenuis of the Coral Sea. Helv. Chim. Acta 1994, 77, 51-58. [CrossRef]

40. Guzii, A.G.; Makarieva, T.N.; Svetashev, V.I.; Denisenko, V.A.; Dmitrenok, P.S.; Pokanevich, E.V.; Santalova, E.A.; Krasokhin, V.B.; Stonik, V.A. New ceramides from sea sponge Oceanapia sp. Russ. J. Bioorg. Chem. 2006, 32, 288-294. [CrossRef]

41. Guzii, A.G.; Makarieva, T.N.; Denisenko, V.A.; Svetashev, V.I.; Rodkina, S.A.; Dmitrenok, P.S.; Anastyuk, S.D.; Stonik, V.A. New cerebrosides from the marine sponge Oceanapia sp. Russ. Chem. Bull. 2006, 55, 928-933. [CrossRef]

42. Capon, R.J.; Skene, C.; Liu, E.H.-T.; Lacey, E.; Gill, J.H.; Heiland, K.; Friedel, T. The isolation and synthesis of novel nematocidal dithiocyanates from an Australian marine sponge, Oceanapia sp. J. Org. Chem. 2001, 66, 7765-7769. [CrossRef] [PubMed]

43. Capon, R.J.; Skene, C.; Liu, E.H.-T.; Lacey, E.; Gill, J.H.; Heiland, K.; Friedel, T. Nematocidal thiocyanatins from a southern Australian marine sponge Oceanapia sp. J. Nat. Prod. 2004, 67, 1277-1282. [CrossRef] [PubMed]

44. Ichiba, T.; Scheuer, P.J.; Kelly-Borges, M. Sponge-derived polyunsaturated $\mathrm{C}_{16}$ di- and tribromocarboxylic acids. Helv. Chim. Acta 1993, 76, 2814-2816. [CrossRef]

45. Matsunaga, S.; Okada, Y.; Fusetani, N.; van Soest, R.W.M. An antimicrobial $\mathrm{C}_{14}$ acetylenic acid from a marine sponge Oceanapia species. J. Nat. Prod. 2000, 63, 690-691. [CrossRef] [PubMed]

46. Santalova, E.A.; Makarieva, T.N.; Ponomarenko, L.P.; Denisenko, V.A.; Krasokhin, V.B.; Mollo, E.; Cimino, G.; Stonik, V.A. Sterols and related metabolites from five species of sponges. Biochem. Syst. Ecol. 2007, 35, 439-446. [CrossRef]

47. Makarieva, T.N.; Stonik, V.A.; Ponomarenko, L.P.; Kalinovsky, A.I. Isolation of (24R)-24,25-methylene-5 $\alpha$-cholestan-3 $\beta$-ol, a new cyclopropane-containing sponge sterol. J. Chem. Res. 1996, 10, 468-469. [CrossRef] 